\title{
Morphologic Bilateral Differences of Top Level Gymnasts
}

\author{
Diferencias Morfológicas Bilaterales de Gimnastas de Nivel Superior \\ "Ivan Cuk; "Maja Bucar Pajek; "Barbara Jakse; "*Jernej Pajek \& ****Mojca Pecek
}

CUK, I.; PAJEK, M. B.; JAKSE, B.; PAJEK, J. \& PECEK, M. Morphologic bilateral differences of top level gymnasts. Int. J. Morphol., 30(1):110-114, 2012.

SUMMARY: Gymnastics is a basic sport, which was developed under a philosophic idea "Mens sana in corpore sano". Such an idea supposes harmonized body and soul. We can also understand under such a terminus the symmetricity of the athletic body. Aim of our investigation was to determine whether gymnast's body is symmetric. On the sample of 40 top level gymnasts (average age of 23 years) who were attending World Cup Competition in Ljubljana in the year 2000 we measured 13 anthropometric characteristics - joint diameters, circumferences and skinfold thicknesses on the left and right side. While there were no differences between the left and right leg parameters, there were some significant differences between the left and right arm measures. We found significant differences in elbow diameter, circumference of forearm, and skin fold thicknesses of triceps and biceps brachii. It is beneficial for coaches to control the symmetry of their athletes as the differences may be a sign of single-sided arm overload and predict acute or chronic injuries.

KEY WORDS: Anthropometrics; Bilateral differences; Male; Artistic gymnastics.

\section{INTRODUCTION}

Gymnastics is a basic sport activity which is considered as a polystructural conventional sport (all the movements are predefined and evaluated by the judges) (Matveyev, 1977). As it is a very basic sport it has a long tradition, with the International Gymnastic Federation (FIG) being founded in 1881 (FIG, 1981) and shortly thereafter the first competition was organized. The first World Championship was held in 1903 in Antwerpen, Netherlands. Today male gymnasts compete on Floor, Pommel Horse, Rings, Vault, Parallel Bars and High Bar apparatuses (FIG, 2009).

Gymnastics has been the focus of various research already between the world wars, when Bach (Skerlj, 1934) performed anthropometric measurements at the Olympic Games 1928 in Amsterdam, Netherlands and concluded that shorter persons probably stand a better chance of succeeding in gymnastics while taller persons are more likely to succeed in track and field.

The most important step in gymnastics development was the change of apparatus constructions, which became pre-tensed and more elastic (Gregorka \& Vazzaz, 1984; Goetze \& Uhr, 1994; Spieth, 1989). Exercises became more and more complex, but the main idea of harmonized body development remained. One sided predomination of load on the human body is not characteristic in gymnastics (on the floor predominate bilateral leg take-offs and landings (Marinsek, 2010; Cuk \& Karacsony, 2004), the same stands for vault (Karacsony \& Cuk, 2005), on the rings both arms have parallel loads (Cuk \& Karacsony, 2002), and high bar exercises (Gaverdovskij, 1987). The most often occurring higher one-sided load is on the pommel horse (Karacsony \& Cuk, 1998) and parallel bars, where one arm support more often happens on the dominant arm and the elements with turns have different loads on left and right side of the body (Gaverdovskij). One sided overload can be a cause for injuries (Bucar Pajek \& Pajek, 2009).

Today experts believe that the hours of training have tripled (from 2-hour training a day in the 30s to 5-6 hour training sessions in the modern era). Arkaev \& Suchilin, (2004) reported that gymnasts train 1500 hours per year in 300-310 days. From the year 1933 up to 2000 gymnast's body height and weight was not changed, but there were changes in shoulders and hips width, where nowadays gymnasts have wider shoulder and narrower hips, this being a consequence

\footnotetext{
* Faculty of Sport, University of Ljubljana, Gortanova 21, 1000 Ljubljana, Slovenia.

** University Medical Center, Zaloska cesta 7, 1525 Ljubljana, Slovenia.

${ }^{* * * *}$ Faculty of Education, University of Ljubljana, Kardeljeva ploscad 16, 1000 Ljubljana, Slovenia.
} 
of more complex movements with more rotations around longitudinal and sagital axis (Cuk et al., 2007).

Soviet authors Rozin \& Ceburaev (1981) followed gymnasts height at Olympic Games (OG) in 1964 and 1980, which varied from 1.66 up to $1.69 \mathrm{~m}$. Lebedev \& Rozin (1981) published results of morphological characteristics of their gymnastics masters of sport: body height $1.66 \mathrm{~m}$, weight $63 \mathrm{~kg}$, interesting are proportions between body height and arm length (44.3\%), leg length (54.4\%) and trunk length (29.7\%). They emphasized the relation between body height, and length of long bones, which was mostly proportional. Cuk \& Novak (1985) defined successful gymnast as the one who is short (the ratio between the length of trunk and the length of legs should be such that the muscles can quickly move these levers), light and has a strong chest with a relatively high and good quality muscular mass and has a very little subcutaneous fat. Claessens et al. (1991) carried out measurements of anthropometric characteristics in top gymnasts at the 1987 World Championship in Rotterdam. They measured 15 anthropometric characteristics, calculated Rohrer index and somatotype according to Heath and Carter.

In 2000, a World Cup in Male Gymnastics was organized in Ljubljana. The meeting was attended by 40 competitors, two of them Olympic Champions (Gervasio Deffer from Spain and Szilvester Csollany from Hungary), and many medal winners from European and World Championships. This event presented an opportunity to measure physical characteristics of top male gymnasts. Since there is lack of knowledge on bilateral morphological differences in gymnasts, aim of our investigation was to determine whether gymnast's body is symmetric. We compared extremity joint diameters, circumferences and skin folds to evaluate symmetry.

\section{MATERIAL AND METHOD}

The sample of measured gymnasts consisted of 40 top male competitors, aged between 17 and 30 years (on average 23 years) who participated at World Cup in Gymnastics in Ljubljana in 2000 and voluntary participated in measurements. Anthropometric measurements were taken at the Faculty of Sports, Ljubljana University. Left and right side were measured by two independent qualified persons. Reliability coefficient of morphologic measurements is 0.99 (Strel \& Sturm, 1981).

Measurements were performed with standard anthropometrical instruments (anthropometer, classic weigher, millimetric tape and skinfold calliper). Following the International Biological Program method, the following anthropometric variables were measured:

- Body weight

- Body weight

- Circumference of left and right side of forearm, upper arm relaxed, thigh, calf.

- Diameter of left and right side: of elbow, wrist, knee.

- Skinfold thickness of left and right side biceps brachii, triceps brachii, forearm (volar), thigh (volar) and calf (medial).

We calculated the measures of central tendency and dispersion, then performed paired $t$-test between left and right side, results with $\mathrm{p}<0.05$ were considered significant.

\section{RESULTS}

Average gymnasts body height was $168 \mathrm{~cm}$, their body weight was $66 \mathrm{~kg}$ which is in accordance with the previous authors (Skerlj; Rozin \& Ceburaev; Claessens et al; Cuk et al.) (Table I).

More detailed information about male gymnasts as reported from Claessens et al. is revealed in Table II. Compared to their results, our gymnasts were slightly higher and heavier. There are interesting differences in some of the variables, where gymnasts in the year 2000 have lower knee diameter, skinfold thickness of triceps brachii and higher circumference of thigh, and relaxed upper arm. Probably nowadays the gymnast's body is optimized by size, but there are some clearly evident changes in mass proportion.

When we compare gymnasts with basketball or football players (Rexhepi \& Brestovici, 2010) or volleyball players (Almagià et al., 2009) it can be seen that gymnasts are shorter and lighter, with much less skinfold.

\section{DISCUSSION}

While we found no differences between left and right side in any of the leg parameters, some of the differences between left and right arm were significant. The following significant differences between left and right arm were found:

- elbow diameter,

- circumference of forearm,

- skinfold thickness of triceps brachii,

- skinfold thickness of triceps brachii. 
Table I. Descriptive statistics and t-test.

\begin{tabular}{|c|c|c|c|c|c|c|}
\hline Variable & $\mathbf{X}$ & SD & Max & Min & & \\
\hline Age (years) & 23.40 & & 30 & 17 & & \\
\hline Body height (cm) & 168.08 & 6.25 & 185.50 & 157.40 & & \\
\hline \multirow[t]{3}{*}{ Body weight (kg) } & 66.45 & 8.15 & 84.80 & 51.90 & & \\
\hline & \multicolumn{2}{|c|}{ Left side } & \multicolumn{2}{|c|}{ Right side } & & \\
\hline & Mean & SD & Mean & SD & $\mathbf{t}$ & Sig. \\
\hline Wrist diameter $(\mathrm{cm})$ & 6.04 & 0.36 & 6.08 & 0.37 & -1.706 & .096 \\
\hline Elbow diameter $(\mathrm{cm})$ & 6.79 & 0.41 & 6.86 & 0.43 & -2.808 & $.008 *$ \\
\hline Knee diameter $(\mathrm{cm})$ & 8.79 & 0.54 & 8.78 & 0.54 & .333 & .741 \\
\hline Ankle diameter $(\mathrm{cm})$ & 6.94 & 0.59 & 6.90 & 0.65 & 1.397 & .170 \\
\hline Circumference of thigh $(\mathrm{cm})$ & 54.07 & 2.84 & 54.02 & 2.85 & -.640 & .526 \\
\hline Circumference of calf $(\mathrm{cm})$ & 35.50 & 1.87 & 35.55 & 1.88 & -.339 & .736 \\
\hline Circumference of forearm $(\mathrm{cm})$ & 27.78 & 1.49 & 28.09 & 1.53 & -3.069 & $.004 *$ \\
\hline Circumference of relaxed upper arm $(\mathrm{cm})$ & 33.15 & 2.12 & 33.26 & 2.16 & -.896 & .376 \\
\hline Skinfold thickness of thigh - ventral (mm) & 7.22 & 2.04 & 7.03 & 1.74 & 1.143 & .260 \\
\hline Skinfold thickness of calf (mm) & 5.01 & 1.31 & 4.88 & 1.27 & 1.261 & .215 \\
\hline Skinfold thickness of biceps brachii (mm) & 3.26 & 0.51 & 3.10 & 0.45 & 2.050 & $.047 *$ \\
\hline Skinfold thickness of triceps brachii (mm) & 4.63 & 1.03 & 4.94 & 1.19 & -3.407 & $.002 *$ \\
\hline Skinfold thickness of forearm - volar (mm) & 3.40 & 0.72 & 3.43 & 0.69 & -.483 & .632 \\
\hline
\end{tabular}

*significant differences between left and right side.

Table II. Anthropometric characteristics of top gymnasts at World Championships in Rotterdam 1989 ( $\mathrm{N}=165)$ (Claesens et al. 1991).

\begin{tabular}{lcccc}
\hline Measurement & X & SD & Max & Min \\
\hline Body heigth (cm) & 167.0 & 6.3 & 183.8 & 153.2 \\
Body weight (kg) & 63.6 & 6.2 & 80.5 & 50.0 \\
Knee diameter (cm) & 9.2 & 0.4 & 11.0 & 8.2 \\
Circumference of thigh (cm) & 51.1 & 2.7 & 58.0 & 36.9 \\
Circumference of forearm (cm) & 27.5 & 1.2 & 30.1 & 24.0 \\
Circumference of relaxed upper arm (cm) & 31.2 & 1.7 & 36.5 & 26.3 \\
Circumference of calf (cm) & 34.7 & 1.7 & 40.0 & 31.0 \\
Skinfold thickness of calf (mm) & 4.7 & 1.2 & 10.2 & 2.8 \\
Skinfold thickness of biceps (mm) & 3.3 & 0.5 & 5.0 & 2.4 \\
Skinfold thickness of triceps (mm) & 5.4 & 1.1 & 10.2 & 3.7 \\
\hline
\end{tabular}

It may be speculated that the asymmetric training loads are the main reason for such a result, with the dominant influence from the exercises on the pommel horse.

It seems that gymnasts do overload dominant arm and the effects are evident as a bigger elbow diameter, with more forearm muscles and bigger skinfold thickness of triceps brachii and lower values of skinfold thickness of biceps brachii. According to Arkaev \& Suchilin high per- formance gymnasts perform 180.000-200.000 elements per year. By Karácsony \& Cuk the highest amount of training hours are devoted to the pommel horse exercises (more than a third); also, the longest duration of exercises are on the pommel horse and these are composed predominantly of circles. A gymnast performs around 45 circles in an exercise, while on other apparatuses only about 20 elements are typically executed. Single sided load can be found also on parallel bars, where many turns in support and hang are lead 
with the dominant arm. However up to now the differences in bilateral morphological characteristics were not reported. As the changes in morphological characteristics may be a sign of an adaptive body process it would be wise for coaches to control the symmetry of their athletes as the differences may be a sign of excessive single-sided arm overload and predict subsequent acute or chronic injuries.

Present analysis of gymnasts' bilateral morphological differences revealed the asymmetry in some of the arm anthropometric parameters in the contrast to what would be expected according to the nature of the sport. While leg anthropometric characteristics - joint diameters, circumferences and skinfold thickness were not significantly different according to body side, we found some significant differences in arm characteristics. Presumably, the asymmetric influence from the training loads (originating mainly from the pommel horse and parallel bars exercise) are the cause of these differences. It is important for coaches to control the symmetry of their athletes as the differences may be a sign of single arm overload and therefore predict acute or chronic injuries. Since this is to the best of our knowledge the first report on bilateral differences in gymnasts it would be wise to continue with the research in this area to further verify our results.

CUK, I.; PAJEK, M. B.; JAKSE, B.; PAJEK, J. \& PECEK, M. Diferencias morfológicas bilaterales de gimnastas de nivel superior. Int. J. Morphol., 30(1):110-114, 2012.

RESUMEN: La gimnasia es un deporte básico, que se desarrolló bajo la idea filosófica "Mens sana in corpore sano". Tal idea supone armonizar el cuerpo y el alma. También la podemos entender bajo el término simetricidad del cuerpo atlético. El objetivo de nuestra investigación fue determinar si el cuerpo de una gimnasta es simétrico. Sobre una muestra de 40 gimnastas de alto nivel (promedio de edad de 23 años) que asistían a la Competencia de la Copa Mundial en Ljubljana en el año 2000 se midieron 13 características antropométricas, diámetros de las articulaciones, perímetros y pliegues cutáneos en los lados izquierdo y derecho. Si bien, no hubo diferencias entre los parámetros de la pierna izquierda y la derecha, hay algunas diferencias significativas entre las medidas del brazo izquierdo y derecho. Se encontraron diferencias significativas en el diámetro del codo, la circunferencia del antebrazo y grosor del pliegue cutáneo del tríceps y del bíceps braquial. Es beneficioso para los entrenadores controlar la simetría de sus atletas, ya que las diferencias pueden ser un signo de sobrecarga del miembro de un lado, y predecir las lesiones agudas o crónicas.

PALABRAS CLAVE: Antropometría; Diferencias bilaterales; Hombre; Gimnasia artística.

\section{REFERENCES}

Almagià, F. A. A.; Rodriguez, F. R.; Gomez, F. O. B.; Arce, P. J. L.; Marincovich, D. I. \& Gutierrez, O. B. Anthropometric Profile of Professional Volleyball Sudamerican Players. Int. J. Morphol., 27:53-7, 2009.

Arkaev, L. J. \& Suchilin, N. G. How to make champions. Moscow, Fiskultura I Sport, 2004.

Bucar Pajek, M. \& Pajek, J. Low back pain and the possible role of Pilates in artistics gymnastics. Sci. Gymnastics J., 1:55-61, 2009.

Claessens, A. L.; Veer, F. M.; Stijnen, V.; Lefevre, J.; Maes, H.; Steens, G. \& Beunen, G. J. Anthropometric characteristics of outstanding male and female gymnasts. J. Sports Sci., 9:53-74, 1991.

Cuk, I. \& Karácsony, I. Rings: methods, ideas, curiosities, history. Norman, Paul Ziert and Associates, 2002.

Cuk, I. \& Karácsony, I. Vault. Ljubljana, STD Sangvincki, 2004.
Cuk, I. \& Novak, D. Testi in norme motoricnih sposobnosti in morfoloskih znacilnosti za izbor nadarjenih deckov za sportno gimnastiko. Ljubljana, Fakulteta za sport, Institut za kineziologijo, 1985.

Cuk, I.; Korencic, T.; Tomazo-Ravnik, T.; Pecek, M.; Bucar, M. \& Hraski, Z. Differencies in morphologic characteristics between top level gymnasts of year 1933 and 2000. Coll. Antropol., 31: 613-9, 2007.

FIG. 100 Years of International Gymnastics Federation 18811981. Moutier, FIG, 1981.

FIG. Code of Points - Artistic Gymnastics for Men. Laussane, FIG, 2009.

Gaverdovskij, J. K. Gimnastičeskoe mnogobore mužskie vidi. Moskva, Fiskultura I Sport, 1987.

Goetze, A. \& Uhr, J. Mond salto. Nordlingen, Gym books, 1994. 
Gregorka, B. \& Vazzas, J. Razvoj telovadnega orodja. Begunje, Elan, 1984.

Karácsony, I. \& Cuk, I. Floor Exercises. Ljubljana, S`TD Sangvincki, 2005.

Karácsony, I. \& Cuk, I. Pommel Horse Exercises. BudapestLjubljana, Hungarian gymnastics Federation and Faculty of Sport, 1998.

Lebedev, N. I. \& Rozin, E. J. Osobenosti fiziceskovo razvitia perspektivnih gimnastov 13 - 18 let. Gimnastika, 1:3941, 1981.

Marinsek, M. Basic landing characteristics and their application in artistic gymnastics. Sci. Gymnastics J., 2:59-67, 2010.

Matveyev, L. P. Fundamentals of Sports Training. Moscow, Fiskultura I Sport, 1977.

Rexhepi, A. M. \& Brestovci, B. The Differences in Body Volume and Skinfold Thickness Between Basketball Players and Footballers. Int. J. Morphol., 28:1069-74, 2010.

Rozin, E. J. \& Ceburaev, V. S. Vozrastnie i rosto-vesovie pokazateli ucastnikov XXII olimpijskih igr. Gimnastika, 1:35-9, 1981.

Spieth, R. Geschichte der Turngeraete. Beschreibung: Fèderation Internationale de Gymnastique, 1989.

Strel, J. \& Sturm, J. Zanesljivost in struktura nekaterih motoricnih sposobnosti in morfoloskih znacilnosti sest in pol letnih ucencev in ucenk. Ljubljana, Visoka sola za telesno kulturo, Institut za kineziologijo, 1981

Skerlj, B. Antropoloska preiskava tekmovalcev. SOKO, 78:211-7, 1934.
Correspondence to:

Prof. Ivan Cuk, Ph.D.

Podpeska 51

1351 Brezovica pri Ljubljani

SLOVENIA

Mobile phone: + 38631233271

Fax: + 38615207740

Email: ivan.cuk@fsp.uni-lj.si

Received: 09-08-2011

Accepted: 21-11-2011 